\title{
Innovation in the 'New Normal' Interactions, the Urban Space, and the Low Touch Economy: The Case of Rio de Janeiro in the Context of the COVID-19 pandemic
}

\author{
Diego Santos Vieira de Jesus ${ }^{1}$, Daniel Kamlot ${ }^{1} \&$ Veranise Jacubowski Correia Dubeux ${ }^{1}$ \\ ${ }^{1}$ Executive Master Program in Creative Economy Management, ESPM-Rio, Brazil \\ Correspondence: R. do Rosário, 90 - Centro, Rio de Janeiro - RJ, 20041-002, Brazil.
}

Received: June 16, 2020

Accepted: July 20, 2020

Available online: July 22, 2020

doi:10.11114/ijsss.v8i5.4900

URL: https://doi.org/10.11114/ijsss.v8i5.4900

\begin{abstract}
The aim of this paper is to examine how innovation was implemented in the city of Rio de Janeiro, in the context of the COVID-19 pandemic, regarding the "new normal" interactions, the urban space and the low touch economy. The main argument indicates that the use of new information and communication technologies to interact with others allowed people to develop social and emotional ties in the light of health precautions. Although many of these precautions were ignored by people using the urban space, some people made new uses of the open natural spaces in Rio de Janeiro to release anxiety and depressive feelings, but the city still faces problems regarding the privatization of public spaces. In the light of the development of the low touch economy, innovation was necessary for many companies to overcome obstacles such as broken relationships with customers, the instant drop in demand, the constraints in supply and production, the political instability and the cash-flow/financial constraints. These solutions included the improvement of the logistic process and alternative branding, the switch to a similar but digital/remote service and the creation of products for other needs of the existing clients.
\end{abstract}

Keywords: innovation, new normal, urban space, low touch economy, COVID-19, Rio de Janeiro

\section{Introduction}

The main public health problems in the contemporary world come from pandemics and epidemics - such as Avian influenza, SARS, Ebola and pandemic influenza - which threaten the health of populations in the world. In 2020, the COVID-19 pandemic spread quickly around the globe, affecting millions of people. It is believed that other and more serious pandemics may be inevitable, though no one can predict when it will occur. Because of this, explaining infectious diseases threats to the general public and encouraging people to adapt their health behaviours is an important element on the public health agenda, such as hygiene (e.g., covering the mouth and nose when coughing or sneezing, washing hands, using hand sanitizers, keeping surfaces clean and avoiding sharing personal items) and social distancing, as Davis et al. (2015) already indicated before the COVID-19 pandemic.

The effects of the novel coronavirus were felt not only in the definition of a "new normal" situation in people's everyday lives - in which they needed to reconfigure their forms of sociality based on social distancing and the avoidance of agglomerations - and their relation to urban spaces, but also in the development of economic activities. According to Chen, Tan and Chan (2020), the "new normal" relates to sustainable enhanced universal precautions. D’Olivo et al. (2018, p.394) state that it concerns coping with uncontrollable events, since "individuals and families affected by life disruptions tend to seek out a 'reconfigured lifestyle' by constructively making use of 'tenuous and emerging social groups and resources"'. The expression has been used in recent times in diverse circumstances, refering to something not previously habitual which became usual after a particular event happened (Cahapay, 2020). Rearding the urban spaces, they embrace some variables which relate to each other, such as local economy, local inhabitants, community life, service level, and physical place (Al-Mashaykhi \& Hammam, 2020), and a good quality urban space is the one that allows individuals and groups to enjoy a sociable space which facilitates passive and active engagement (Carmona et al., 2010).

The low touch economy refers to a new state of the economy, a result of the COVID-19 pandemic control and mitigation health measures which led to behavior shifts and economic disruption. The low touch economy is 
characterized by low-touch interactions, health and safety measures, and permanent industry shifts, such as the design of factory floors for the safety of workers, the use of online tools and apps such as Zoom to interact and work, the replacement of human interactions in service businesses by robots and the substitution of offline events for virtual ones. Companies in the era of the "new normal" created by the pandemic will have to adapt their business models in a context of instability to work with the different health measures and other challenges that COVID-19 and future epidemics and pandemics may bring, such as the constraints on business-as-usual with the reduction of physical interactions between employees and consumers, travel bans, new hygiene measures, limitations on large gatherings and the isolation of vulnerable groups. At the same time, these companies will have to create high impact via innovations and improved business models, as well as be flexible to navigate multiple aftershocks in the global economy to succeed. While some companies consider the low touch economy in their long-term plan, others are beginning to work with scenarios that do not forecast a short-term recovery (Board of Innovation, 2020).

Regions with stricter policies are expected to recover sooner, and, to ensure compliance, several regions may use invasive surveillance and tracking tools in combination with hefty fines for rule-breakers. However, these strict policies adopted in many Asian countries to combat the COVID-19 pandemic do not seem to get support in large parts of Europe and the Americas, particularly in Brazil (Board of Innovation, 2020). Brazil eased quarantine before reaching peak deaths, and its states began to relax measures of social distancing while the country still recorded successive records of new cases and deaths and rates of contagion. The World Health Organization (WHO) recommended some criteria for easing social distancing, but Brazil only fit some of them. According to the WHO, the new cases must be sporadic and concentrated in certain places at a level that does not overburden the health system. A country must also conduct mass tests to identify the cases and their contacts and isolate and treat everyone. It is necessary to protect places more vulnerable to outbreaks, such as poor communities, and to take measures to reduce the risk of transmission of the virus in workplaces. It is also important to try to prevent the import and export of cases and ensure the population is aware and committed to actions to combat the pandemic. Brazil was doing well in the prevention of imported and exported cases because the borders were closed, and the population was considerably aware of the pandemic's dynamic. Even though the isolation has not been respected by many Brazilians, the explosion of new cases and deaths and the lack of a national policy for testing and investigating contagions and isolating cases were still problems. One of the first criteria for relaxing quarantines is that a country has passed the peak of the pandemic, and there was no evidence that Brazil had reached its peak. The mismatch of messages from state and municipal governments, which implemented the quarantines, and the federal government, which opposed these measures, hindered adherence to social distancing in Brazil, which was not enough to reduce the rate of contagion to satisfactory rates. The cases continued to rise, but popular pressure also increased to return to normalcy with the reopening of trade. States and municipalities yielded to these calls even in very non favorable conditions, which should further aggravate the impacts of the pandemic (Barifouse, 2020).

In early June 2020, the governor of the state of Rio de Janeiro, Wilson Witzel, allowed the opening of bars, restaurants, shops, malls, sights and religious temples, but demanded that every person used masks and hand sanitizers and the venues to work with up to the 50\% of their capacity. However, the mayor of the city of Rio de Janeiro, Marcelo Crivella, said that he would only authorize the general reopening of trade if Witzel's decision were supported by the scientific council of the municipality, which brings together specialists in public health (Platonow, 2020). Despite the uncertainties in the city regarding the decision of opening the commercial venues when the COVID-19 pandemic had not already reached its highest point in the state of Rio de Janeiro, many people in the city started to implement innovations to build "new normal" interactions, redefine their use of the urban space and develop activities related to the low touch economy.

The aim of this article is to examine how innovation was implemented in the city of Rio de Janeiro, in the context of the COVID-19 pandemic, regarding the "new normal" interactions, the urban space and the low touch economy. The main argument indicates both "health individualism" and interpersonal responsibilities towards others influenced people's actions and the use of new information and communication technologies to interact with others did not replace completely social proximity, but allowed people to develop social and emotional ties in the light of health precautions. Although many of these precautions were ignored by people using the urban space, some people made new uses of the open natural spaces in Rio de Janeiro to release anxiety and depressive feelings, but the city still faces problems regarding the privatization of public spaces, which are not available for every citizen. In the light of the development of the low touch economy, some organizations that already operated with online business had a positive revenue growth through the demand surge during the COVID-19 pandemic and after the crisis, but, for some sectors on which the city depends on, the effect was catastrophic, such as tourism. Innovation was necessary for many companies to overcome obstacles such as broken relationships with customers, the instant drop in demand, the overall uncertainty, the constraints in supply and production, the political instability and the cash-flow/financial constraints. These solutions 
included the improvement of the logistic process and alternative branding, the switch to a similar but digital/remote service, and the creation of products for other needs of the existing clients. So, this study contributes in the sense that the growing transformation and harnessing of the urban spaces derived from the social distancing caused by the outbreak of COVID-19 in Rio affected companies and created new business models to adapt to new consumer needs, relevant to be understood.

The article followed a logical and reflective structure, which emphasized interpretation and argumentation (Severino, 2000). After exposing the general developments regarding the "new normal" interactions, the urban space, and the low touch economy in the context of the COVID-19 pandemic, it highlighted the specific situation of the city of Rio de Janeiro, the geographical unit of analysis. The methodology addresses the analysis of recent texts on the situations of the world, Brazil, and Rio de Janeiro in the light of the outbreak of the COVID-19 pandemic and the flexibilization of the quarantine in Rio de Janeiro in June 2020. A qualitative approach was used, focused on data provided by bibliographic and documental sources, which were examined and interpreted to bring about meaning, understanding and accurate knowledge (Bowen, 2009).

Items identified as corresponding to the situation of the "new normal" interactions, the urban space and the low touch economy were examined in the bibliographic research carried out in recent works, which allowed a reflection through an approach in which characteristics present in the exposed context were analyzed and eventually linked to actions of the players in the city. The research went through the following steps: bibliographical research; data collection; data evaluation; pertinent information definition; data interpretation according to document analysis; information analysis and findings (Borden, 2009). This structure allowed the consolidation of the main relevant concepts, avoided duplication and helped to identify potential gaps in the literature produced.

\section{Innovation: Theory and Discussion}

According to Schumpeter (1997), the development of capitalism involves encouraging innovation, since it encompasses technical changes in favor of creating competitive advantages for companies. Such advantages - which, for the author, may be present in the product, the service or the process of the production chain - would bring dynamism to the economy and promote cycles driven by a "creative destruction". The capacity and initiative of entrepreneurs, supported by the discoveries of scientists and inventors, would create opportunities for investment, growth, and employment. Schumpeter (1997) argued that innovation would involve situations such as the introduction of new products, with novelties for consumers and characteristics superior to existing goods; the creation and implementation of new production methods, not yet tested by the market; the opening of a market not explored by companies in the same industry; the discovery of a new source of inputs or the reformulation of an organizational structure, with the creation or elimination of a monopoly.

Science and technology became institutionalized as forms of contribution to economic growth after World War II, as was clear in Bush's (1945) "linear model of innovation". The model understands technical change as a sequence of stages in which developments in scientific research would lead to processes of invention, followed by applied research and technological growth. Thus, marketable products and processes would be introduced from high investments in research by scientific and technological policies (Conde \& Araújo-Jorge, 2003). However, this perspective has been gradually questioned, as the simple investment of capital in research and development would not necessarily lead to economic or technological development.

More recently, innovation came to be understood in a more comprehensive way, not only as the simple creation of something new, but as a task of providing new human and material resources to generate wealth (Drucker, 1985). It is not necessarily limited to total creation and can also encompass the reframing of processes and products, ranging from original scientific discoveries to new uses for existing technologies, new business models or the provision of products or services to new locations and customers (Ries, 2012). More broadly, innovation refers to the search, discovery, experimentation, development and adoption of new products, processes and organizational techniques (Dosi, 1988).

In general, innovations are usually classified as incremental or disruptive. The first are minor changes, carried out in successive ways and capable of generating changes in the economy and society. The disruptive ones occur less frequently than incremental ones but have the power to cause market and social changes (Igliori, 2002). Such innovations need not necessarily be technical, but bring changes - which may be of a technological, organizational, administrative or social nature, for example - that occur through complex and interactive processes, encompass multiple economic and social agents and incorporate different types of information and knowledge (Feitosa, 2011).

Technological innovations bring changes in goods and services offered to society or in the way in which they are created and made available. They can be compromised if the benefits of financial and emotional investments do not materialize within a reasonable time - which may be the result of changes in sectorial leaders - nor are properly perceived due to the exacerbation of competitiveness and the misconduct in the process (Plonski, 2005). Organizational 
innovations can occur when there are changes in the culture of an institution, particularly in its basic values. This culture is responsible for constituting the organizational structures and strategies, initially established by the leaders of the organizations (Ismail \& Abdmajid, 2007). Social innovations are characterized as new and recognized responses to the promotion of social changes, which bring together three attributes: the satisfaction of human needs that are not met by the market; the promotion of social inclusion and the training of agents to face processes of exclusion and marginalization, which can trigger a transformation of power relations (André \& Abreu, 2006). To create an environment conducive to innovation, institutions need to develop physical, organizational, technological and socio-cultural infrastructures that create subsidies for the generation and diffusion of innovations, as well as public policies that can stimulate the innovation process (Feitosa, 2011; Jesus, 2020).

Based on the subjects presented, we will now discuss innovation, from the perspective of the "new normal" interactions, the urban space and the low touch economy.

\subsection{Innovation in the "New Normal" Everyday Interactions}

It is possible to say that, once COVID-19 has been successfully suppressed, businesses, consumer demand, and routine activities such as traffic jams, kids going to school again and family parties may return to normal with health restrictions. People will get used to health checks, masks, and rearranged workplaces. Even though the situation will not be the same as before, it will be "normal" quite soon, such as the missing of shops and restaurants, the delivery of groceries and digital university degrees, for example. Nevertheless, some new things will not feel normal in the new situation, such as security gates, health checks, court proceedings via Zoom and the wearing of mouth masks. The "new normal" will bring changes in mobility because crowded public transport will be avoided as much as possible and personal car usage will quickly recover. In car sharing, passengers and drivers will be asked to wear masks. Certainly, some industries will take a long time to recover. For example, travel bans and limitations on large gatherings will impact the tourism and event industries for years to come. Where the authorities decide not to enforce strong restrictions, the COVID-19 and other epidemics and pandemics will continue to spread, which may bring economic instability. Unless consumers accept sickness and death as acceptable by-products of their interactions, it is unlikely the economy in many of these environments will fully recover (Board of Innovation, 2020).

The COVID-19 pandemic required people to reconfigure their forms of sociality, and "distancing" or "locking down" may have high costs and be not easily sustainable in the long term, or at least until effective vaccines or antivirals are available. The social distancing measures adopted by many countries has fuelled concerns about the damage they would wreak economically and psychologically. Quarantine could heighten anxiety, and isolation may lead to depression. The official advice, which has been published in the media during the pandemic, encouraged citizens to experiment with the opportunities digital technologies offer for socializing in alternative ways. However, the access to such technologies is unevenly distributed, as well as the benefits of such interactions. Relationships in which physical presence is extremely important - such as those with young children and people who live alone and are deprived of the multiple benefits that come from physical co-presence with others - will be the most damaged ones. The calculative attitude towards others threatens to strain many relationships and injure individuals' self-worth. The pressures of long-term co-residence in close confinement should be considered, especially when parents must combine the demands of working from home with those of caring for children whose schools have closed. In the perception of many people, the fighting against COVID-19 is being imagined as the adoption of radical asociality, characterized by lockdown and enforced or voluntary immobilization. What is problematic about the default patterns of social interaction is not the brute fact of social interaction, but rather the way that the rhythms and volatility of regular social interaction lead to a tremendous number of different people getting connected up in a transmission chain. The recognition of this clarifies the key criteria that render an intervention effective. The "social containment language" in the "new normal" could allow people to see their network of relationships as tools they can collaboratively manipulate to contain and control the pandemic's spread whilst still enjoying the varied companionship they need for a life worth living (Long, 2020).

Both "health individualism" and their interpersonal responsibilities towards important others may influence people's actions. Social proximity appears to be important, which means that those others who are close to oneself in terms of social and emotional ties and living situation are factored into health precautions. However, many people still see pandemics such as the COVID-19 as a personal, though distant, health threat. They may see themselves at risk, but not as a risk to unknown others, such as a person sitting beside them on public transport. This is how "health individualism" manifests in the public. In the context of a pandemic, people wish to be informed about it, but many still reserve the right to interpret and apply advice according to their own situation. In some occasions, public health guidance on hygiene and social distancing may be endorsed, but its utility may be found to have practical and long-term limitations, because social interaction is fundamental to daily life, as well as to the transmission of the disease (Davis et al., 2015).

The internal benefits of social distancing evidently come from the fact that someone is less likely to get sick, and the 
external benefit is the fact that people are less likely to get others sick, particularly strangers. However, while individuals may internalize the cost of social distancing, the optimal policy should innovate in the sense of recognizing that individuals may ignore the external benefit of reducing the risk of transmitting illness. In the light of this possibility, optimal policy should internalize the effect of an additional sick person on the quality of health care available to inframarginal individuals (Farboodi, Jarosch \& Shimer, 2020).

The "new normal" started to be developed in Rio de Janeiro with the implementation of international hygiene protocols in public transportation, such as buses, trains, and subways (G1 Rio, 2020). Even though the use of new information and communication technologies to interact with others did not replace completely social proximity, it allowed the people to develop social and emotional ties in the light of health precautions. One example is the use of new technologies such as Zoom or WhatsApp calls for interactions among family members and friends, especially in occasions such as birthdays and other celebrations. The live performances of many artists based in Rio de Janeiro in social networks in the internet were ways not only to guarantee the economic survival of many of these professionals, but also to promote the online engagement of people with the artists and among themselves in the comments during the live performances. An example is the live performances of the samba singer Teresa Cristina on her Instagram account, which brings together approximately 6,000 people daily. The repertoire of Brazilian music usually gains exciting interpretations amid the buzz of anonymous and famous people, who interact with the singer and among themselves in the comments. In addition to the songs presented by the singer, the chats range from jokes to politics and history classes. Teresa Cristina saw in the online live performances an unpretentious way to overcome the pain of isolation and ended up becoming a phenomenon of prestige and popularity. The program, created without a sponsor or exquisite production, brings the spontaneity of the "possible parties" in the pandemic period (Tinoco, 2020a).

The implementation of social innovations during the pandemic was evident in many poor communities in Rio de Janeiro. Although the new coronavirus's contagion emerged in the richest areas of the city, several poor communities in Rio de Janeiro already had confirmed cases by the municipal administration, such as Vidigal, Mangueira and Cidade de Deus. The lack of tests and the irregular incidence in the search for care are factors that block the identification of cases in these communities. The hashtag \#Covid19NasFavelas was created to talk about the topic on social networks. In Rocinha, one of the largest favelas in Rio, the collection and distribution of basic goods and hygiene kits were possible because members of social organizations were connected through WhatsApp information channels. They used WhatsApp to coordinate action and cancel public events. In the Alemão Complex, community leaders created a crisis office, a space for dialogue and creation of solutions according to the reality of the community. The office has made posters and created messages on the community radio and in sound cars to raise money to buy food (Komukai, 2020). Due to the great challenge of quarantining communities, the social movement SOS Comunidades da Zona Portuária prevented entrances and exits from the poor communities in the port area of the city and helped to preserve the support of basic supplies through virtual crowdfunding in places that are on the margins of urban projects in the gentrification processes of the port area, which has undergone an urban reconfiguration with forced, physical and affective displacements before the 2016 Olympic Games (SOS Comunidades da Zona Portuária, 2020).

\subsection{Innovation in the Urban Space}

Some measures such as urging people to stay home during the COVID-19 pandemic were taken to reduce the number of close physical interactions. Social distancing has disrupted the everyday lives of entire populations, and sudden disruptions to everyday life may impact human well-being, particularly among populations that live in dense urban settings with limited public space. Besides the fact that some people are parts of risk groups, many also suffer from anxiety and depression from social distancing. With these extraordinary circumstances of social distancing, urban nature could offer resilience for maintaining well-being. In circumstances of voluntary social distancing, in which people are still allowed to visit outdoor environments, urban nature can provide people with opportunities to escape confinement and enjoy positive well-being effects, preserve social relationships even with due distance and provide a sense of connection with the outside world (Jennings \& Bamkole, 2019; Weimann, Björk, \& Håkansson, 2019).

Ensuring nature access for the public should be a fundamental strategy of cities when coping with crisis, as is evident in the COVID-19 pandemic situation and informed by the memory of historical insights. The social distancing can induce feelings of loneliness, with negative consequences, such as increased risks of anxiety, depression, premature mortality, post-traumatic stress symptoms, confusion, and anger. Older people, which is the most encouraged group to keep social distance, also are the most vulnerable to isolation impacts. Sheltering in place with family members may also pose risks to well-being due to a drastic increase in domestic violence in many countries during the COVID-19 pandemic. Concerning this situation, cities may need to innovate by accepting crises as a new reality and finding ways to function during these disturbances. Maintaining or increasing space for nature in cities and keeping it accessible to the public should be part of the sustainability agenda. The urban nature provides a refuge and escape from household confinement, and the absence of stressors of physical confinement combined with positively contributing factors of natural 
environments likely help to momentarily reduce stress and provide relaxation in times of uncertainty (Barton \& Pretty, 2010). Social relationships may be maintained even in the context of social distancing, especially during psychological hardships, and contact with nature can also provide urban residents with a sense of coherence and biophilic connections, which help people to deal with stressors and stay physically healthy. The city resilience may be extremely important when the COVID-19 social distancing orders are gradually liberalized, which shows that cities need to accept new crises regimes as a new reality and find ways to function during them (Samuelsson et al., 2020).

In this context, spatial organisation and property rights arrangements are fundamental aspects for city resilience in the emergence of new crisis such as the COVID-19 pandemic. Plenty of space in cities needs also be allocated to nature for the sake of residents' well-being. The avoidance of extreme densities, over-connected street networks and monofunctional neighbourhoods entails possibilities for residents to easier shift their spatial habits to feature more nature environments in crisis times. Urban nature that is easy to access for residents provides more health benefits and is more valued and appreciated, especially during social distancing. Regarding the property-rights arrangements, the right to enjoy benefits of nature interaction tends to be part of the urban sustainability agenda, but there is a global demise of public space, accessible to everyone with no restriction and one that fosters communication and interaction, in the light of urban neoliberal policies and the privatization of public space, such as public parks. The revenues from rents and property taxes can make park restoration and management feasible, but typically it occurs at the expense of public green space. This needs to be revised by public authorities and the population in the context of the enhancement of city resilience during emerging crisis (Samuelsson et al., 2020).

Many people in Rio de Janeiro have been making new uses of public spaces and developing new habits, such as the practice of physical activities such as yoga and jogging and the relieving of stress and anxiety of confinement through contact with nature in the Tijuca Forest and the surroundings of Guanabara Bay, although not always respecting the rules for the use of masks. However, a major problem concerns the policies related to some public spaces, which are no longer available to all citizens of the city and reveal the political opportunism in the face of the crisis caused by the COVID-19 pandemic. In April 2020, Environment Minister Ricardo Salles suggested to authorities in the federal executive branch that the government should take advantage of the fact that people were focused on the pandemic to pass a "herd" of changes in legislation. In the City Council of Rio de Janeiro, the 1418/2019 and 174/2020 bills forwarded on an urgent basis, and with no evident relationship to the health crisis - authorize changes in the city's urban patterns. The first, approved in May 2020, allows the construction of buildings with up to 18 floors around the Rio das Pedras community, in the neighbourhood of Jacarepaguá. The second, currently being evaluated, makes urban planning rules more flexible in exchange for financial compensation. It allows, for example, the construction of hotels on slopes and the increase in projects on the fringe of the slums (Tinoco, 2020b).

\subsection{Innovation in the Low Touch Economy}

Some companies were already going bankrupt in some weeks during the COVID-19 pandemic, and others could not hire fast enough to cope with rising demand. Once the health crisis is under control, some sectors of the economy will go back to a normal state, but not all. Many organizations will need to be redesigned to recover, considering the external interaction, the staffing, the high-risk benefits, the personal safety, the physical workplace, and the travel policies. Regarding the external interaction, the companies need to limit third-party interactions, change interaction formats, screen external collaborators, develop and expand new business models for customer touchpoints and interactions and consolidate entrances and exits to control traffic, as well as external-guest registration. In relation to the staffing, the companies will have to consider a distributed workforce, identify jobs that might be fulfilled remotely full time, reduce store hours, close locations, and spread attendance by appointment. Regarding the high-risk benefits, they will need to consider compensation adapted to risk and promote salary adaption and pre-payment of bonuses. When the companies deal with personal safety, they will have to develop new protocols to respond to positive cases, employee risk profiling and quarantine policies, as well as limit the number of on-site people and eventually replace them by automation. In the physical workspace, the need to reduce the risk of virus spread will bring new cleaning protocols and spatial configurations to limit interaction. The travel policies will limit public transport, establish strict travel rules and create new travel behaviors, such as the use of mouth masks and screening. No-essential business travel will be avoided (Board of Innovation, 2020).

Some organizations may have a positive revenue growth through the demand surge during the COVID-19 pandemic and after the crisis, such as e-commerce, while the impact for others can be mildly negative, such as consumer goods, or severe, such as oil and gas. For some sectors, the effect may be catastrophic, with a sustained revenue loss of more than $50 \%$, such as tourism. The biggest obstacles for most companies now are the broken relationships with customers and the instant drop in demand. Other related problems are the overall uncertainty, which makes it difficult to plan; the constraints in supply and production; the political instability and the cash-flow/financial constraints (Board of Innovation, 2020). 
Some companies may have short-term opportunities to grow, such as platforms to connect with remote customers, tools to support e-commerce, healthy food delivery at home, safe at-home workouts, and alternatives for supply chain. Others may copy the solutions from the front-runners when the key need is to improve their core. These solutions may include the improvement of the logistic process and alternative branding. The companies may also explore adjacent opportunity spaces, such as the switch to a similar but digital/remote service and the creation of products for other needs of the existing clients (Board of Innovation, 2020).

However, if the companies need to make a more ambitious move, potentially jumping to white-space opportunities in the low touch economy, they will need to operate with more uncertainty and keep an eye on new habits to understand where potential white spaces can emerge. The new consumers behaviors may be extremely relevant as white-space triggers, because, when people act differently, they face new needs which may represent opportunities for companies. Consumers will start to use new products and services, such as in-home health and wellness (at-home sport for kids, short-term rental equipment programs and local neighborhood coops). Some companies do not need to offer a new B2C product but focus on B2B tools to help other companies that will deal with the consumers' emerging needs. For example, some services may help event businesses set up virtual alternative solutions, tourism organizations launch and scale marketing campaigns towards local tourists and recording and IT services for universities to create remote programs (Board of Innovation, 2020).

Industry shifts - such as redesigned supply chains and new market entrants - also have high relevance as white-space triggers in the low touch economy, as well as societal changes, such as shift in demographics and new norms and values. Among the industries shifts, the centralized supply chains will be split up to have more redundancy to handle disruptions. This brings opportunities for services for nearshoring, forward shipping, new logistic processes, and cost-efficient local production, such as automation services. These shifts may also lead to more distributed businesses, and hygiene restrictions will force offices, restaurants and theaters, for example, to split up large venues into smaller local units. When companies split up locally, supply chains and processes need to be redesigned as well. Digital native players may enter traditional markets, and virtual migration may become more common, because more businesses may move to remote-first business models and create an opportunity for players abroad to "migrate virtually" and enter a local market. Regarding societal changes, the rise of extremism and polarization in combination with health concerns will help to sell protection services, as well as safety and security products. As the older generation needs extra support with IT services to participate in a remote-first society, younger people may support older people in their lives, and many families can resume meeting up in large groups, so services for weddings and parties need to be reinvented to enable people to feel safe when they do. With more extensive activity monitoring, remote learning will demand more tools to identify and track students to prevent cheating. Working from home creates a similar push, which can make many employers want to see evidence of working hours and attendance. Consumers may also want to see more transparency in the supply chain to know who has interacted with the products they are using and if these employees were safe (Board of Innovation, 2020).

The establishment of new regulation - especially legal hurdles that are removed and can open new markets - have medium relevance, while new technology - that makes it easier to solve specific problems - and the access to new resources - such as assets and partnerships - have low relevance as white-space triggers in the low touch economy. When new regulations are considered, the benefits of introducing remote and digital tools to deal with legal issues may be enormous, as well as the challenges related to authentication, fairness, accessibility, and privacy. So far, the COVID-19 crisis and its aftershocks have not fuelled a rapid acceleration of new tech development beyond the health sector. The rapid adoption of digital services in general will continue, but this will be probably due to a shift in consumer behavior, not because of the discovery of new technologies that opened new markets. Regarding the access to new resources/assets, some local companies will benefit from a reshuffle in supply chains and new business networks, but it is not possible to say that this shift will be a white-spaces trigger (Board of Innovation, 2020).

In Rio de Janeiro, the growing digital transformation that has been much discussed in recent years affected companies and created new business models. Since the beginning of the social distancing, immersive experiences, and digital activities such as the live performances of singers and bands who live in the city and virtual tours promoted by some city museums have been developed. Many companies had already adopted, before the pandemic, the measure of once or twice a week for home office work due to the difficulty of commuting and to reduce costs. With the requirement of social distancing, some functions started to perform the work at a distance, connected by digital platforms. Activities that required face-to-face work also had the impact of changes, with more distant workstations. One of the more affected economic sectors of the city was tourism, on which Rio de Janeiro depends a lot. In the light of the crisis caused by the COVID-19, some tourism professionals needed to innovate and exchanged face-to-face tours in Rio de Janeiro's attractions for virtual tours in Facebook lives with software used in video game streaming. Many professionals of this sector now live on voluntary contributions from virtual tourists who accompany them on online itineraries 
focused on architecture in places such as Mauá Square and Cinelândia (Vessoni, 2020).

\section{Conclusion}

Innovation does not necessarily imply, as Ries (2012) argues, the total creation of something new, but the reframing of products and processes, such as new business models and the provision of products or services to new locations and customers. Regarding the "new normal" interactions, in the light of the "health individualism" and interpersonal responsibilities that people have towards important others (such as members of the family and friends), the use of new information and communication technologies allowed the interaction with others to develop social and emotional ties in the light of health precautions, such as birthdays and other celebrations. New uses for existing technologies - such as the use of digital live performances as a way of entertainment and engagement with other people - were disseminated, which can be considered a type of innovation. Other innovations to deal with the limitations of the "new normal" interactions could be seen in the implementation of international hygiene protocols in public transportation - the provision of new health services to the population - and the creation of spaces of collaboration for the distribution of basic goods, crowdfunding and debates on important issues for the poor communities through digital means. According to André and Abreu (2006), social innovations such as these ones are responses to the promotion of social changes to satisfice human needs.

Innovations were also implemented in the ways in which the population dealt with the urban space, despite the difficulties. Rio de Janeiro is known for being a city with many areas for physical activities in open and green spaces where people can walk, run or ride a bicycle (Aterro do Flamengo, Lagoa, Jardim Botânico, Recreio dos Bandeirantes, Tijuca Forest etc.). Nevertheless, this space is limited to the use of few residents, and most of the peripheral neighborhoods suffer from the lack of leisure regions. Due to the brutal inequality in the distribution of income and the large areas with precarious housing with no basic infrastructure, Rio de Janeiro's poor communities are a clear portrait of the inequality of rights to the use of urban spaces. Even before the COVID-19 crisis, federal programs for investments in structuring and preserving public spaces such as parks and squares in several cities in Brazil were rare, and this was no different in the city of Rio de Janeiro (Domingues, 2020).

However, as Dosi (1988) argues, innovation also refers to the discovery and adoption of new processes and organizational techniques. Many people in Rio de Janeiro who needed to relieve the stress and the anxiety caused by confinement and social distancing saw in physical activities such as yoga and jogging a way not only to adapt their lives to the conditions of prolonged stress, but also redefine their relation with the environment. In relation to green areas, it is also worth remembering that Rio de Janeiro has large university campuses, former convents and seminars now closed, but with large areas of land, headquarters of companies and rural districts, where little investment could bring important urban planning solutions and create points of great interest. Besides the restructuring of these places for the creation of new relations between people and the urban environment, it is also necessary to introduce a new economic model which is more associated with public space and integrated with the urban environment. This should preserve green and natural elements and create more fluid and sustainable spaces. The need for consumption itself needs to be revised, as well as the ways that garbage can be better used (Lira, 2020).

The new economic model will probably follow the guidelines of the "low touch economy". Feitosa (2011) argues that innovations may be of a technological, organizational, administrative, or social nature and occur through complex and interactive processes, encompass multiple economic and social agents, and incorporate different types of information and knowledge. In the light of the negative impacts of the COVID-19 pandemic on numerous economic sectors, innovation was necessary for many companies in Rio de Janeiro to overcome obstacles such as broken relationships with customers, the instant drop in demand, the overall uncertainty, the constraints in supply and production, the political instability and the cash-flow/financial constraints. The solutions encompassed the improvement of the logistic process and alternative branding, the switch to a similar but digital/remote service, and the creation of products for other needs of the existing clients. In the city, these innovations could be detected in the development of immersive experiences and digital activities such as live performances and virtual tours promoted by museums and the dissemination of new organizational practices in home office work.

In the "new normal", the rhetoric of "social distancing" has heightened popular consciousness of how individual actions can affect population health, driving people away from spaces posing high levels of epidemiological risk. However, the emphasis on "distance" and "isolation" has led to measures that are considered as "unliveable" by some people. These measures only come to fruition if a state force literally coerces people to stay within their homes. The public health discourse needs to combine an emphasis on what citizens must not do with positive visions for how people could reconfigure the ebbs and flows of their interactions in ways that safeguard the relationships that make life worth preserving (Long, 2020). It is important to mention that emphasising individual responsibility in risk communication may amplify discrimination against people with different biomedical vulnerabilities and encourage those who consider 
themselves healthy to think of themselves as "at risk", but not "a risk" to others (Davis et al., 2015).

Regarding the urban space, nature contact may provide positive well-being effects in the "new normal" situation, while still allowing for social distancing. The access to urban nature is fundamental for urban resilience, because, in the short term, it provides buffering capacity during a pandemic for maintaining mental and physical health, social relationships and communion with the natural world. At the same time, the arrangement of space and property rights need to ensure access to urban nature, which will be fundamental for building general urban resilience in the long term (Samuelsson et al., 2020).

Many organizations may face problems regarding their adaptation to the "new normal" and the low touch economy, especially the broken relationships and the drop in demand. The broken relationships may be caused by the inaccessibility of points of sale and the restrictions regarding physical interactions. The first cause relates both to B2B and B2C contexts, when clients are limited to interactions with sales reps because the use of a physical point of sale is not possible. The solutions for this problem may encompass the enabling of salespeople to guide customers remotely via live video and audio, the making of photorealistic scans of properties to offer clients virtual tours, the sending of prototypes to customers to discuss via video and the shipping of multiple items to the clients, who can pick and buy the items they are interested in and return the rest (Board of Innovation, 2020).

Regarding the second cause, some service businesses may need to rethink how they create a new experience with no large groups of people interacting with each other. The solutions for this may be many. The restaurants may switch to service meals in small compartments for added safety while maintaining the social experience. Actors and singers may switch to private showings for limited audiences. The establishment of time restrictions may determine how long a client can visit a business. The expansion of drive-through services and appointment-based models may also represent solutions for many sectors (Board of Innovation, 2020).

The drop in demand may be caused by product safety concerns of some clients. To deal with this, robots may be used in some places such as hospitals and hotels to disinfect rooms with UV light. Public dashboards may help track the health status of everyone involved in the production and delivery of a product. The professions that require close physical contact - such as dentistry - need to implement additional screens and protective gear. The establishment of new safety labels and certificates may pop up sales, and the redesign of some products with antiviral materials, disposables and easy cleaning and disinfecting may also have a positive effect (Board of Innovation, 2020).

\section{References}

Al-Mashaykhi, B. A., \& Hammam, R. A. (2020). Shared Street as A Means of Liveable Urban Space. IOP Conf. Series. Earth and Environmental Science, 409(012044), 1-11. https://doi.org/10.1088/1755-1315/409/1/012044

André, I., \& Abreu, A. (2006). Dimensões e espaços da inovação social. Finisterra: Revista Portuguesa de Geografia, 41(81), 121-141. https://doi.org/10.18055/Finis1465

Barifouse, R. (2020). Coronavírus: na contramão do mundo, Brasil flexibiliza quarentena antes de atingir pico de mortes. $B B C$ Brasil [WWW page]. Retrieved from

https://www.terra.com.br/noticias/brasil/coronavirus-na-contramao-do-mundo-brasil-flexibiliza-quarentena-antes-d e-atingir-pico-de-mortes,368b3c5a964ec09d2024d07e4e5be6ddufh9oh74.html

Barton, J., \& Pretty, J. (2010). What is the best dose of nature and green exercise for improving mental health- A multi-study analysis. Environmental Science and Technology, 44(10), 3947-3955. https://doi.org/10.1021/es903183r

Board of Innovation (2020). The winners of the Low Touch Economy. Board of Innovation website [WWW page]. Retrieved from https://www.boardofinnovation.com/low-touch-economy/

Bowen, G. (2009) Document analysis as a qualitative research. n, G. (2009). Qualitative Research Journal, 9(2), 27-40. https://doi.org/10.3316/QRJ0902027

Bush, V. (1945). As we may think. Atlantic Monthly, 176(1), 101-108.

Cahapay, M. B. (2020). Rethinking Education in the New Normal Post-COVID-19 Era: A Curriculum Studies Perspective. Aquademia, 4(1), ep20xx. https://doi.org/10.29333/aquademia/8315

Carmona, M., Heath, T., Tiesdell, S., \& Oc, T. (2010). Public Places - Urban Spaces: the Dimensions of Urban Design (2nd ed.). London: Routledge.

Chen, R. C., Tan, T. T., \& Chan, L. P. (2020). Adapting to a new normal? 5 key operational principles for a radiology service facing the COVID-19 pandemic. European Radiology [On-line Serial]. https://doi.org/10.1007/s00330-020-06862-1 
Conde, M. V. F., \& Araújo-Jorge, T. C. (2003). Modelos e concepções de inovação: a transição de paradigmas, a reforma da C\&T brasileira e as concepções de gestores de uma instituição pública de pesquisa em saúde. Ciências \& Saúde Coletiva, 8(3), 727-741. https://doi.org/10.1590/S1413-81232003000300007

D’Olivo, P., Rozendaal, M. C., Giaccardi, E., Grootenhuis, M. A., \& Huisman, J. (2018). Reconfiguring a New Normal: A Socio-Ecological Perspective for Design Innovation in Sensitive Settings. The Journal of Design, Economics, and Innovation, 4(4), 391-406. https://doi.org/10.1016/j.sheji.2018.10.003

Davis, M., Stephenson, N., Lohm, D., Waller, E., \& Flowers, P. (2015). Beyond resistance: social factors in the general public response to pandemic influenza. Public Health, 15(436), 1-9. https://doi.org/10.1186/s12889-015-1756-8

Domingues, E. (2020). Como devem ser as cidades "pós-pandemia"? CBN [WWW page]. Retrieved from https://www.cbnvitoria.com.br/cbn_vitoria/entrevistas/2020/05/como-devem-ser-as-cidades-pos-pandemia-101420 4461.html

Dosi, G. (1988). Sources, Procedures, and Microeconomic Effects of Innovation. Journal of Economic Literature, 26(3), $1120-1171$.

Drucker, P. F. (1985). Innovation and Entrepreneurship: Practices and Principles. New York: Harper \& Row.

Farboodi, M., Jarosch, G., \& Shimer, R. (2020). Internal and external effects of social distancing in a pandemic. NBER Working Paper Series, Working Paper 27059 [On-line Serial]. https://doi.org/10.3386/w27059

Feitosa, C. O. (2011). A importância da inovação para o desenvolvimento econômico local. Revista Econômica Política do Desenvolvimento, 4(12), 29-50.

G1 Rio. (2020). Linhas 1 e 2 do MetrôRio e BRT passam por higienização neste sábado para conter o coronavírus. G1 [News Bulletin]. Retrieved from

https://g1.globo.com/rj/rio-de-janeiro/noticia/2020/03/28/linhas-1-e-2-do-metrorio-passam-por-higienizacao-nestesabado-para-conter-o-coronavirus.ghtml

Igliori, D. C. (2002). Economia dos Clusters industriais e Desenvolvimento. São Paulo: FAPESP.

Ismail, W. K. W., \& Abdmajid, R. (2007). Framework of the culture of innovation: a revisit. Journal Kemanusiaan 9 , $38-49$.

Jennings, V., \& Bamkole, O. (2019). The relationship between social cohesion and urban green space: An avenue for health promotion. International Journal of Environmental Research and Public Health, 16(452), 1-14. https://doi.org/10.3390/ijerph16030452

Jesus, D. S. V. (2020). Para além da criatividade: os processos de inovação em setores criativos e as suas contribuições às áreas tradicionais da economia. In: D. Pereira (Org.). Tendências epistemológico-teóricas das ciências sociais aplicadas 2 (pp.91-0104). Ponta Grossa: Atena Editora. https://doi.org/10.22533/at.ed.3912012059

Komukai, D. (2020). Maiores favelas do Brasil se organizam contra Covid-19, pedem ações do estado e empatia de quem vê de fora. Ecoa. [News Bulletin]. Retrieved from https://www.uol.com.br/ecoa/reportagens-especiais/a-favela-alerta/index.htm\#tematico-2

Lira, P. (2020). Como retornar à vida em comunidade no mundo pós-pandemia? ArchDaily Brasil.[WWW Page]. URL https://www.archdaily.com.br/br/938922/como-retornar-a-vida-em-comunidade-no-mundo-pos-pandemia

Long, N. J. (2020). From social distancing to social containment: reimagining sociality for the coronavirus pandemic. Medicine Anthropology Theory (Submitted).

Platonow, V. (2020). Crivella diz que só reabre comércio do Rio com apoio de especialistas. Agência Brasil [News Bulletin]. Retrieved from

https://agenciabrasil.ebc.com.br/geral/noticia/2020-06/crivella-diz-que-so-reabre-comercio-do-rio-com-apoio-de-es pecialistas

Plonski, G. A. (2005). Bases para um movimento pela inovação tecnológica no Brasil. São Paulo em Perspectiva, 19(1), 25-33. https://doi.org/10.1590/S0102-88392005000100002

Ries, E. (2012). A Startup Enxuta: como os empreendedores atuais utilizam a inovação contínua para criar empresas extremamente bem-sucedidas. São Paulo: Lua de Papel.

Samuelsson, K., Barthel, S., Colding, J., Macassa, G., \& Giusti, M. (2020). Urban nature as a source of resilience during social distancing amidst the coronavirus pandemic. Landscape and Urban Planning. (Preprint). https://doi.org/10.31219/osf.io/3wx5a

Schumpeter, J. A. (1997). Teoria do Desenvolvimento Econômico. São Paulo: Nova Cultural. 
Severino, A. J. (2000). Metodologia do trabalho científico. São Paulo: Cortez.

SOS Comunidades da Zona Portuária (2020). SOS Comunidades da Zona Portuária. Retrieved June 7, 2020, from https://www.kickante.com.br/campanhas/sos-comunidades-da-zona-portuaria

Tinoco, P. (2020a). A hora da estrela Teresa Cristina. Veja Rio [On-line serial]. Retrieved from https://vejario.abril.com.br/beira-mar/teresa-cristina-lives/

Tinoco, P. (2020b). 'Passando a boiada': mudança na legislação urbanística do Rio já começou. Veja Rio [On-line serial]. Retrieved from https://vejario.abril.com.br/cidade/projetos-urbanisticos-aprovados/

Vessoni, E. (2020). Guias e condutores de turismo se reinventam em tempos de pandemia. UOL [WWW Page]. Retrieved from

https://www.uol.com.br/nossa/noticias/redacao/2020/05/18/guias-e-condutores-de-turismo-se-reinventam-em-temp os-de-pandemia.htm

Weimann, H., Björk, J., \& Håkansson, C. (2019). Experiences of the urban green local environment as a factor for well-being among adults: An exploratory qualitative study in southern Sweden. International Journal of Environmental Research and Public Health, 16(2464), 1-14. https://doi.org/10.3390/ijerph16142464

\section{Copyrights}

Copyright for this article is retained by the author(s), with first publication rights granted to the journal.

This is an open-access article distributed under the terms and conditions of the Creative Commons Attribution license which permits unrestricted use, distribution, and reproduction in any medium, provided the original work is properly cited. 